\title{
Effects of selenium administration on blood serum Se content and on selected reproductive characteristics of sheep (short communication)
}

\begin{abstract}
Effects of selenium on certain indicators of sheep reproductive success and on Se level in the sheep's blood serum were studied in 2001-2002 on 100 Polish merino sheep ewes kept in a Western Pomeranian sheep farm. The 100 ewes were picked out on random and divided into two equal groups: treatment and control. The blood samples for serum Se assays were collected prior to administration of sodium selenide (before servicing) and 7 days after the treatment. The study was aimed at determining Se effects on the reproductive success (fecundity) of ewes and on selected indicators of lamb utility in a Se-deficient area. Se administration prior to servicing enhanced the herd's reproductive success. The treatment group's litter size was by 0.38 lamb per ewe higher than that of the control. The control group lamb body weight was lower than that of the treatment group by an average of $0.23 \mathrm{~kg}$ on birth and $0.31 \mathrm{~kg} 33$ days later.
\end{abstract}

Key Words: sheep, selenium, fertility, weight gain

\section{Zusammenfassung}

Titel der Arbeit: Wirkung einer Selenbehandlung auf den Se-Gehalt im Blutserum und auf ausgewählte Faktoren der Schafproduktion (Kurzmitteilung)

Die Wirkung von Selen auf ausgewählte Faktoren der Schafproduktion und auf den Se-Gehalt im Blutserum von Schafen wurde in den Jahren 2001-2002 untersucht. Die Untersuchungen erfolgten in einem Betrieb in WestPommern an 100 polnischen Merinomutterschafen. Die Tiere wurden zufällig ausgewählt und in zwei gleiche Gruppen geteilt: Versuchs- und Kontrollgruppe. Die Blutproben zur Se-Bestimmung im Serum wurden vor und 7 Tage nach der Natriumselenat-Behandlung entnommen. Das Ziel der Untersuchungen war, den Einfluss des Se-Einsatzes auf die Fruchtbarkeit der Mutterschafe und auf die ausgewählten Faktoren der Lämmerproduktion im Se-Mangelgebiet festzustellen. Der Se-Einsatz vor der Deckzeit ergab bessere Reproduktionseffekte der Herde. In der Experimentalgruppe wurden von jedem Mutterschaf 0,38 Lämmer mehr als in der Kontrollgruppe geboren. In der Kontrollgruppe war die durchschnittliche Geburtsmasse der Lämmer um 0,23 kg und am 33. Lebenstag um 0,31 kg niedriger.

Schlüsselwörter: Schaf, Selen, Fruchtbarkeit, Gewichtszunahme

\section{Introduction}

Selenium has been amply documented to significantly enhance animal development, a number of metabolic processes, and the reproductive success. On the other hand, Se deficiency may lead to pathogenic effects such as the white muscle disease, retention of placenta, spontaneous abortions, reduced fertility, and neonatal disorders (BOSTEDT and SCHRAMEL, 1990; HULLAND, 1985; HAMLIRI et al., 1991; GRELA and SEMBRATOWICZ, 1997).

Se is transported to the offspring (lambs) along two pathways: via the placenta during the foetal stage, and with the colostrum at the neonatal phase. Selenium, even at low concentration in the ewe's body, is efficiently passed on to the foetus (KOLLER et al., 1984). Parenteral administration of Se significantly increases its concentrations in the serum blood colostrum and milk (CUESTA at al., 1995; MAUS et al., 1980; RAMISZ 
et al., 2001). According to some authors (NORTON and MCCARTHY, 1986), Se increases the ewe's fecundity and improves health and increases body weight of the neonatal lambs.

The present study was aimed at assessing effects of Se treatment on sheep reproductive characteristics (fecundity) and on some indicators of lamb utility in a Sedeficient area.

\section{Materials and methods}

Effects of Se administration on certain characteristics of reproductive success and Se level in the blood serum were studied in 2001-2002 on the Polish merino sheep kept on a Western Pomeranian farm. A random sample of 100 4-year-old ewes was picked out and divided into two equal groups: treatment and control. The blood for assays (5 $\mathrm{ml}$ samples) was collected from the jugular vein (vena jugularis) of both groups 3 days before and the treated group 7 days after sodium selenide administration. The treatment group sheep received $5 \mathrm{ml} 0.1 \%$ sodium selenide $10-14$ days before servicing and 14 days prior to delivery. The blood serum Se level was assayed fluorometrically using the method developed by WATKINSON (1966). The lambs born in both groups were weighted on birth and 33 days later. The data were processed statistically by calculating means $(\bar{X})$, standard deviations (SD), and coefficients of variation (V) and by testing for significance of between-groups differences with Student's $t$ test run with the STATISTICA PL computer package. The following criteria developed by GRACE (1997) were used to evaluate the sheep blood serum Se level: Se content below $0.041 \mu \mathrm{g} / \mathrm{ml}=$ Se deficiency; $0.041-0.079 \mu \mathrm{g} / \mathrm{ml}=$ threshold level; above $0.079 \mu \mathrm{g} / \mathrm{ml}$ = physiological (regular) level for a sheep herd.

The sheep obtained food by pasture grazing in summer, while in winter they were fed hay, beetroot, and fodder mix applied in rations of 200-250 g a sheep. In addition, saltlicks and mineral mixes were offered as well.

\section{Results}

The blood serum Se selenium content assays showed the herd to be affected by Se deficiency. Prior to Se application, 49 out of 50 ewes were either Se-deficient (41 ewes) or showed threshold Se levels (8 ewes). A sufficient blood serum Se content was shown by a single ewe only. A clear improvement was observed following sodium selenide application: as few as 2 ewes were Se-deficient, 3 showing the threshold level. The blood serum Se contents in the remaining 45 ewes exceeded $0.1 \mu \mathrm{g} / \mathrm{ml}$, which should be regarded, according to standards used by GRACE (1997), FORRER et al. (1991) as optimal for sheep. The mean Se blood serum content in the control was $0.038 \mu \mathrm{g} / \mathrm{ml}$ (3 days before treatment). Statistically significant differences $(\mathrm{P} \leq 0.01)$ in Se contents were detected between the control and the treatment groups (Table 1).

\section{Table 1}

Blood serum Se content in the Western Pomeranian sheep ( $\bar{X} \pm$ SD, V) (Selengehalt im Blutserum bei Schafen der Region Westpommern)

\begin{tabular}{|c|c|c|c|c|c|}
\hline \multirow[t]{2}{*}{ Group } & \multirow{2}{*}{$\begin{array}{l}\text { No. of sheep } \\
\text { assayed (n) }\end{array}$} & \multicolumn{2}{|c|}{ Se content in blood serum $(\mu \mathrm{g} / \mathrm{ml})$} & \multirow[b]{2}{*}{ SD } & \multirow[b]{2}{*}{$\mathrm{V}(\%)$} \\
\hline & & 5 day before treatment & 7 days after treatment & & \\
\hline $\mathrm{K}$ & 50 & $0.038^{\mathrm{A}}$ & 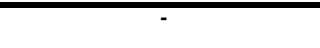 & 0.017 & 44.71 \\
\hline $\mathrm{D}$ & 50 & 0.037 & $0,175^{\mathrm{B}}$ & 0.063 & 36.41 \\
\hline
\end{tabular}


The same groups (A and D) of ewes were used in the experiments presented in Table 2.

Compared to the control group (K), the lambs born by the Se-treated ewes (D) experienced much lower mortality the number of lambs born live low higher (Table 2). The treatment group lambs were significantly $(\mathrm{P} \leq 0.01)$ heavier both on birth and 33 days later, compared to the control group lambs.

Table 2

Effects of selenium on sheep reproductive success and lamb body weight (Der Einfluss von Selengaben auf das Geburtsgewicht, das Gewicht am 33. Lebenstag und die Sterblichkeitsrate)

\begin{tabular}{|c|c|c|c|c|c|c|c|c|c|c|c|}
\hline \multirow{2}{*}{ Group } & \multicolumn{3}{|c|}{ Number of lambs /ewe } & \multicolumn{3}{|c|}{$\begin{array}{l}\text { Body weight on birth } \\
\text { (kg) }\end{array}$} & \multicolumn{3}{|c|}{$\begin{array}{l}\text { Body weight } 33 \text { days } \\
\text { after birth }(\mathrm{kg})\end{array}$} & \multirow[t]{2}{*}{$\begin{array}{l}\text { Mortality } \\
\text { (\%) }\end{array}$} & \multirow{2}{*}{$\begin{array}{l}\text { Number of } \\
\text { lambs born }\end{array}$} \\
\hline & & & & $(\bar{X})$ & SD & V (\%) & $(\bar{X})$ & SD & V (\%) & & \\
\hline K & $1.20^{\mathrm{A}}$ & 0.55 & 42.46 & $3.73^{\mathrm{A}}$ & 0.42 & 11.41 & $11.19^{\mathrm{A}}$ & 0.66 & 5.92 & 8.0 & 60 \\
\hline $\mathrm{D}$ & $1.58^{\mathrm{B}}$ & 0.53 & 30.18 & $3.96^{\mathrm{B}}$ & 0.44 & 11.09 & $11.50^{\mathrm{B}}$ & 0.99 & 8.67 & 12.5 & 79 \\
\hline
\end{tabular}

${ }^{\mathrm{A}, \mathrm{B}}$ results statistically significant at $\mathrm{P} \leq 0.01 ; \mathrm{K}$, control; $\mathrm{D}$, treatment

Application of sodium selenide resulted in improvement of reproductive success indicators (fertility and fecundity) (Table 2).

The Se level increase was translated into lamb body weight gains: in 33 days of live the treatment lamb body weight was by $2.70 \%$ higher than that of the untreated lambs. Following a prophylactic Se treatment applied to ewes at advanced stage of pregnancy, the wite muscele disease was arrested and the lambs were born healthy.

\section{Discussion}

The initial Se-status in blood serum of ewes before treatment was $0.038 \mu \mathrm{g} / \mathrm{ml}$. Comparison with the references values for Se: $0.071 \mu \mathrm{g} / \mathrm{ml}$ to $0.426 \mu \mathrm{g} / \mathrm{ml}$ (FORRER et al., 1991; GRACE, 1997) showed that the flock was affected by Se-deficiency. The results obtained after Se-application show that the Se-concentration in blood serum of treated group was within the references values $(\bar{x}=0.175 \mu \mathrm{g} / \mathrm{ml})(\mathrm{Tab} .1)$.

MAUKA et al. (1998) demonstrated the blood serum Se content in sheep fed Sevitamins enriched dials to be $25 \%$ higher and the increase in the liver to be $35 \%$. The Se level increase was translated into lamb body weight gains: in month 5 of the experiment, the treatment lamb body weight was by $28.6 \%$ higher than that of the untreated lambs.

GABRYSZUK and KLEWIEC (2002) and HEMINGWAY (1994) observed a clear improvement of Se-status in blood serum after sodium selenide application (from $0.036 \mu \mathrm{g} / \mathrm{ml}$ to $0.095 \mu \mathrm{g} / \mathrm{ml}$ ). Several authors observed a positive effect of the Seadministration on reproductive performance of sheep (SEGERSON and GANAPATHY, 1980; RAMISZ and BUZEK, 1986; MIHAJLOVIC et al., 1991). SEGERSON et al. (1986) established that number of lambs born alive from control and Se-treated ewes were 1.61 and 1.81 respectively, and lambs weaned per ewe lambing were 1.1 to 1.5 respectively. RAMISZ and BUZEK (1986) and 
HEMINGWAY (1994) reported the ewes fecundity to be considerably dependent on the feed Se level.

The results presented here are in agreement with the studies discussed above. From Setreated and control ewes 1.58 lambs and 1.20 lamb per ewe were born, respectively. A positive effect of Se-administration was observed on weight of lambs. GABRYSZUK and KLEWIEC (2002) informed that two injections of Se given to ewes before mating and lambing increased the body weight of lambs about $0.7 \mathrm{~kg}$ on 28 day of the experimental group comparing to the control group. The authors established, too, that Se given to ewes increased the average daily weight gain of their lams from birth to 28 days of age. Similar results obtained LANGLANGS et al. (1991) which established higher weight gain in lambs born from ewes fed Se enriched feed compared to the weight gain of lambs born from untreated ewes.

Data obtained in this study are comparable with the finding reported by GABRYSZUK and KLEWIEC (2002) and RAMISZ and BUZEK (1986). Administration of Se increased live weight of lambs at 33 days of age born from treated ewes compared to the control group. In the treated group the mortality of lambs was lower about $4.5 \%$ comparing to the untreated group.

Results obtained in this study indicate that application of Se before mating and lambing significantly effect Se-status in blood serum and reproductive performance of ewes and body weight of lambs at 33 days of age. Before Se-application necessary blood analyses of sheep to establish this microelement level should be conducted.

\section{References}

BOSTEDT, H.; SCHRAMEL, P.:

The importance of selenium in the prenatal and postnatal development of calves and lambs. Biological Trace Element Research 24 (1990), 163-71

CUESTA, P. A.; McDowell, L.R.; KUNKLE, W.E.; WILKINSON, N.S.; MARTIN, F.G.:

Effects of high-dose preparatum injections of Se and vitamin E on milk and serum concentrations in ewes. Small Ruminant Research 18 (1995), 99-103

FORRER, R.; GAUTSCKI, K.; LUTZ, H.:

Comparative determination of selenium in the serum of various animal species and humans by means of electrothermal atomic absorption spectrometry. J. Trace Elem. Electrobytes Health Dis. 5 (1991), 101113

GABRYSZUK, M.; KLEWIEC, J:

Effect of injecting 2- and 3-year-old ewes with selenium and selenium-vitamin $\mathrm{E}$ on reproduction and rearing of lambs. Small Ruminant Research 43 (2002), 127-132

GRACE, N.D.:

Use of biochemical cryteria to diagnose trace element deficiencies in sheep and cattle. In: Proc. of 9th Int. Conf. on Anim. Prod., Free Univ. of Berlin 11-14.09.1997, Verlag Stuttgart 1997.

GRELA, E.R.; SEMBRATOWICZ I. :

Organiczne związki selenu w żywieniu zwierząt [Organic selenium compounds in animal feeding]. Med. Wet., 53 (1997), 385-386

HAMLIRI, A..; OLSON, W.G.; KESSABI, M.; JOHANSON, D.W.: Selenium deficiency in sheep in Morocco : Prophylaxis. 5 (1991), 9-12

HEMINGWAY, R.G.:

The influences of dietary intakes and supplementation with selenium and vitamin $\mathrm{E}$ on reproduction diseases and reproductive efficiency in cattle and sheep. Vet. Res. Commun. 27 (2003), 159-74

HULLAND, T.J:

Muscles and Tendons. In Pathology of Domestic Animals. Third Edn, eds K.V.F. JUBB, P.C. KENNEDY, N. PALMER. Vol.1, (1985), 140-95. London: Academic Press Inc.

KOLLER, L.D.; WHITBECK, G.A.; SOUTH, P.J.:

Trans-placental transfer and colostrums concentrations of selenium in beef cattle. Am. J. Vet. Res. 45 (1984), 2507-2510

LANGLANDS, J.; DONALD, G.; BOWLES, J.; SMITH, A.: 
Subclinical selenium insufficiency. 3. The selenium status and productivity of lambs born to ewes supplemented with selenium. Aust. J. Exp. Agric. 31 (1991), 37-43

MAUKA, J.; BRONICKI, M.; DĘBIŃSKI, Z.:

Profilaktyczne aspekty stosowania preparatu Nutril-Se (Lek Ljubljana) w odchowie jagniąt [Prophylactic aspects of applying Nutril-Se (Lek Ljubljana) in lamb rearing]. Życie Wet. 73 (1998), 2627

MAUS, R.W., MARTZ, F.A., BELYEA, R.L., WEISS, M.F.:

Relationship of dietary selenium to selenium in plasma and milk from dairy cows. J. Dairy Sci., 63 (1980), 532-537

MIHAJLOVIC, M.; LINDEBERG, P.; RAJKOVIC, M.:

Selenium content in feedstuff and selenium status of sheep in some areas of Serbia. In: MOMČILOWIC, B. (Ed.), Trace Elements in Man and Animal, Vol.7. IMI, Zagreb (1991), 11 - 27

NORTON, S.A.; MCCARTHY, F.D.:

Use of injectable vitamin E and selenium-vitamin E emulsion in ewes and suckling lambs to prevent nutritional muscular dystrophy. J. Anim. Sci., 62 (1986), 497-508.

RAMISZ, A.; BALICKA-RAMISZ, A.; PIKUŁA, R.; JASTRZĘBSKI, G.:

Zapobieganie niedoborowi selenu u koni, bydła i owiec na terenie Pomorza Zachodniego [Control of selenium deficiency in horses, cattle and sheep in Western Pomerania Region]. Folia Univ. Agric. Stetin. 224 Zootechnica (2001), 151-156

RAMISZ, A.; BUZEK, T.:

Badania nad wpływem preparatu Evetsel na plenność u owiec [Effects of Evetsel formula on sheep fecundity]. Now. Wet., 3-4 (1986), 225-228

SEGERSON, E.; GANAPATHY, S.:

Fertilization of ova in selenium/vitamin E treated ewes maintained on two planes of nutrition, J. Anim. Sci. 51 (1980), 386-394

SEGERSON, E.; GUNSETT, F.; GETZ, W.:

Selenium-vitamin E supplementation and production efficiency in ewes marginally deficient in selenium. Livest. Prod. Sci. 14 (1986), 149-159

WATKINSON, J.H.:

Fluorometric determination of selenium in biological material with 2, 3-diaminonaphthalene. Anal. Chem. 38 (1966), 92-103

Received: 2005-03-14

Accepted: 2006-03-22

Author's address

ALEKSANDRA BALICKA-RAMISZ, Prof. PhD hab.; BOGUMIŁA PILARCZYK, PhD; ALOJZY RAMISZ, Prof. PhD hab.; MARTA WIECZOREK, MSc

Department of Animal Hygiene and Prophylaxis,

Agricultural University of Szczecin,

ul. Dr Judyma 6

71-466 Szczecin

Poland

E-Mail: A.Balicka-Ramisz@biot.ar.szczecin.pl 